\title{
Corrosivity Evaluation of Copper-Nickel Alloy (90/10) in Pumps Used in Offshore Platforms for Seawater Pumping
}

\author{
Fernando B. Mainier \\ Escola de Engenharia, \\ Universidade Federal Fluminense, \\ Niteroi, Rio de Janeiro, Brazil \\ fmainier@uol.com.br
}

\author{
Alessandro Martins Coelho \\ Escola de Engenharia, \\ Universidade Federal Fluminense, \\ Niteroi, Rio de Janeiro, Brazil \\ coelho.alessandro@ig.com.br
}

\author{
Edilson Ferreira Barros \\ Escola de Engenharia, \\ Universidade Federal Fluminense, \\ Niteroi, Rio de Janeiro, Brazil \\ edbarros.rj0@gmail.com
}

\begin{abstract}
This work discusses the case of corrosion in a coppernickel alloy used in seawater, where chlorination is necessary to control micro- and macro-organism growth that can render inoperable the seawater supply system used in an offshore platform. Studies developed in the last 30 years have shown copper-nickel's adequateness in seawater, with a corrosion rate of about $0.001 \mathrm{~mm} / \mathrm{year}$. However, annual equipment inspection showed localized corrosion in an internal chamber in a stand-by pump. Such corrosion occurred due to high-concentration of sodium hypochlorite $(\mathrm{NaClO})$ injection into the operational system, even for pumps that were out of operation. To evaluate this corrosive process, gravimetric (mass loss) and electrochemical tests were developed in synthetic seawater with $\mathrm{NaClO}$ at concentrations of $100,500,1000$ and $5000 \mathrm{mg} / \mathrm{L}$. The results indicated that the corrosiveness varied from low to moderate. The presence of pitting and crevices observed in the laboratory tests derails or compromises material use in seawater. It was concluded that there is a need for continuous monitoring of the $\mathrm{NaClO}$ injection in seawater pumps, and a method was proposed in order to minimize or avoid a high concentration of chlorine in standby pumps.
\end{abstract}

Keywords-localized corrosion; copper-nickel alloy; sodium hypochlorite; seawater

\section{INTRODUCTION}

The seawater system used in maritime oil production facilities located on the coast of South America is designed to supply units and equipment with water injection. Depending on the purpose of each maritime installation project, seawater can be independent from the utilities and injection wells, except for the fire ring main systems, where pressurization can be used for an extension of the seawater intake system. The depth of seawater intake and the efficiency and integrity of seawater pumps, should be set based on these factors:

- improvement of the seawater to be injected in oil wells,

- cooling system optimization,

- improvement of seawater quality in the dehydration of the natural gas unit,
- reduction of seawater flows involved, and

- reduction of energy consumption.

For many decades, copper-nickel alloys have been used as materials for pipes and equipment for seawater systems, mainly in shipbuilding, offshore oil production platforms, and desalination plants. The main features of this alloy are good corrosion resistance in salt water and greater resistance to erosion than other copper alloys or carbon steel. In addition, copper-nickel alloys are resistant to biofouling, providing multiple economic benefits. Generally, to reduce, minimize and control the growth of biofouling, continuous chlorination using sodium hypochlorite $(\mathrm{NaClO})$ is used, in such a way that the residual free chlorine should be established in the range of 0.2 to $0.5 \mathrm{mg} / \mathrm{L}$. In tropical seawaters the development of microorganisms is very intense, requiring the injection of $\mathrm{NaClO}$. Generally, these submersible pumps on the platforms are inspected every two years. The novelty of this paper is to alert marine equipment inspectors that high concentrations of $\mathrm{NaClO}$ can damage the rotors and internal pumps made of copper-nickel alloy. Operational failures of these seawater suction pumps can cause disruption of oil production. Despite the appropriate properties of this alloy, some failures can occur and compromise the pumping of seawater [1-4]. In this particular case evaluation, the intake and transfer of sea water to different equipment and processes of the platform consists, essentially, of four submerged pumps to a depth of $20 \mathrm{~m}$ protected by a screen to avoid the penetration of sea animals. As shown in Figure 1, to prevent biofouling a solution of $\mathrm{NaClO}$ is injected continuously into a dosing pump to maintain the level of free chlorine at $0.5 \mathrm{mg} / \mathrm{L}$ in the intake of the four pumps. Those pumps were designed to work at $100 \%$ capacity, and the casing and impeller were manufactured from a coppernickel alloy (90/10). The three pumps $(1,2$, and 3$)$ operated in scheduled alternation, while the fourth pump was in standby mode. In the annual equipment inspection, it was observed that the stopped pump had pitting and crevice corrosion located in the internal chamber and in the impeller. It was also observed that this stopped pump continued to receive, continuously, the $\mathrm{NaClO}$ solution injected by the dosing pump. This fact resulted 
in a considerable increase of concentration of $\mathrm{NaClO}$ in the inner chamber, while on the outside of the pump (casing), in contact with sea water and without the presence of $\mathrm{NaClO}$, localized corrosion or pitting were not observed. It is important to note that in the deposits removed inside this pump (in standby) no micro or macro organisms that could cause a microbiologically influenced corrosion (MIC) were identified due to the high concentration of clorine due to $\mathrm{NaClO}$ accumulated inside this pump. Figures 2 and 3 present a view of the seawater suction pump and the dosing pump hypochlorite injection.

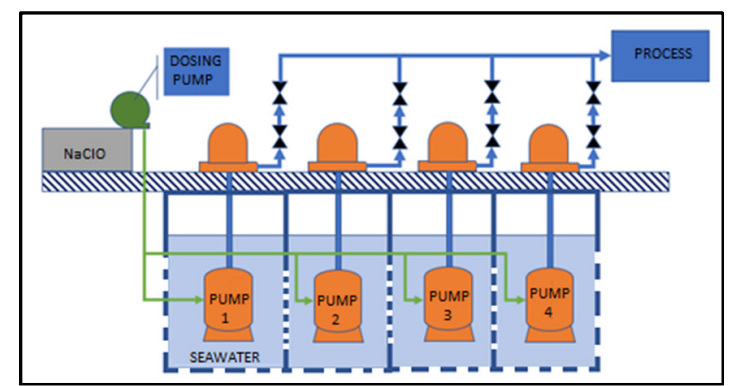

Fig. 1. Diagram of pump intake and seawater transfer

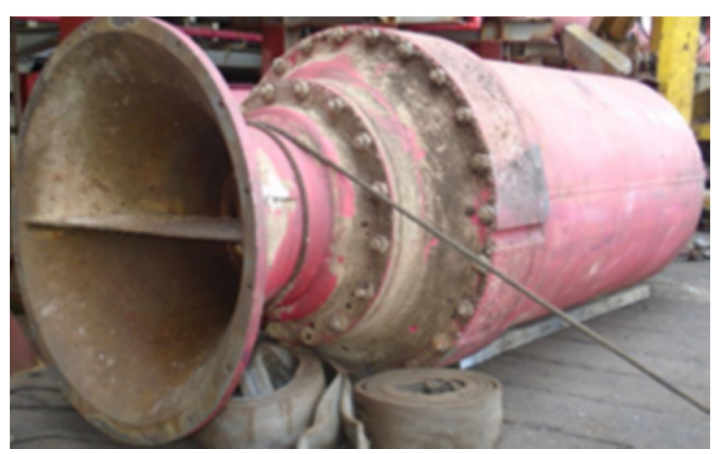

Fig. 2. Seawater suction pump

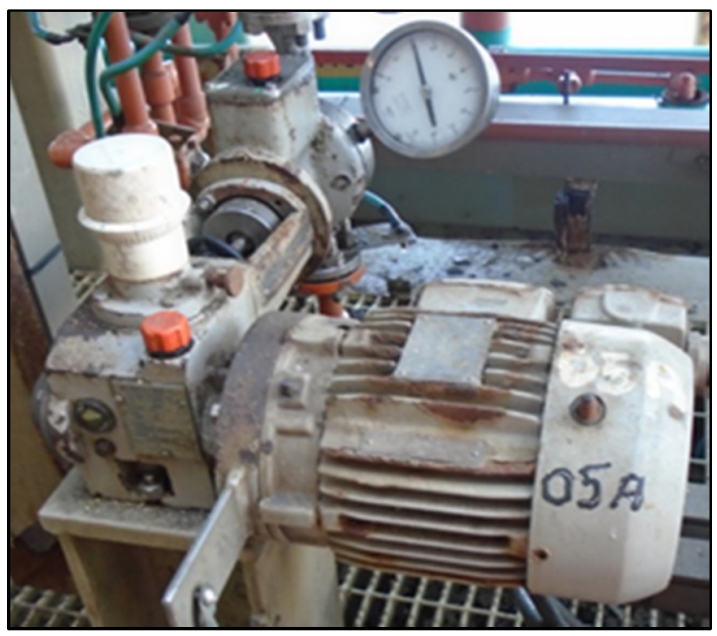

Fig. 3. Hypochlorite injection dosing pump

In order to evaluate the corrosion in the internal chambers of the seawater suction pumps, gravimetric and electrochemical tests were developed, with coupons made with copper-nickel alloy in synthetic seawater with additions of $\mathrm{NaClO}$.

\section{MATERIALS AND METHODS}

\section{A. Gravimetric Tests}

The material evaluated in this work was a copper-nickel alloy sheet $(87.43 \% \mathrm{Cu}, 9.05 \% \mathrm{Ni}, 2.20 \% \mathrm{Fe}$ and $0.98 \% \mathrm{Mn})$ used for the manufacturing of coupons. The coupons used in the gravimetric tests (weight loss) had the following dimensions: $3.50 \mathrm{~cm} \times 1.0 \mathrm{~cm} \times 0.2 \mathrm{~cm}$. The metal surface was prepared with grade 100 to 500 sandpaper. The coupons were cleaned with acetone and ethanol and dried with hot air. The test coupons were weighed with a digital electronic balance. The solutions used in the experiments were characterized as saline water containing $3.5 \%$ (\% mass) $\mathrm{NaCl}, 800 \mathrm{mg} / \mathrm{L}$ of $\mathrm{MgCl}_{2}$ and $600 \mathrm{mg} / \mathrm{L}$ of $\mathrm{CaCl}_{2}$, and the $\mathrm{pH}$ was set at 7.2-8.0. In the saline solutions were added, respectively, in each test, $100 \mathrm{mg} / \mathrm{L}, 500 \mathrm{mg} / \mathrm{L}, 1000 \mathrm{mg} / \mathrm{L}$ and $5000 \mathrm{mg} / \mathrm{L} 10 \%$ by mass $\mathrm{NaClO}$. Gravimetric tests were performed in glass containers with a capacity of $400 \mathrm{~mL}$. The coupons were completely immersed in $250 \mathrm{~mL}$ of saline solution. The glass containers were maintained at a temperature of $25^{\circ} \mathrm{C}$ with a thermostatically controlled bath. The times for testing were fixed at 15, 30 and 60 days of exposure. Immediately after the completion of the test, each coupon was washed with water, pickled with Clark solution for 40s according to ASTM G 3172 [5], cleaned with ethanol and dried with hot air. The corrosion rates (CR) are defined by:

$$
C R=K\left(W_{o}-W_{i}\right) / \rho . S . t \quad(\mathrm{~mm} / \text { year })
$$

where $K$ is a constant equal to $8.76 \times 10^{4}, W_{o}$ and $W_{i}$ are the loss weight in the absence and presence of addition of $\mathrm{NaClO}, S$ is the sample area $\left(\mathrm{cm}^{2}\right), \rho$ is its density $\left(8.9 \mathrm{~g} / \mathrm{cm}^{3}\right.$ for coppernickel alloy), and $t$ is the exposure time (h).

\section{B. Electrochemical Tests}

For the polarization measurements, samples of the coppernickel alloy were cut in order to obtain an electrode surface of $0.20 \mathrm{~cm}^{2}$. The metal surface was then embedded in polyester resin and polished with No. 600 emery paper. Then, the samples were degreased with acetone and washed in distilled water before being inserted in a conventional polarization cell, as shown in Figure 4.

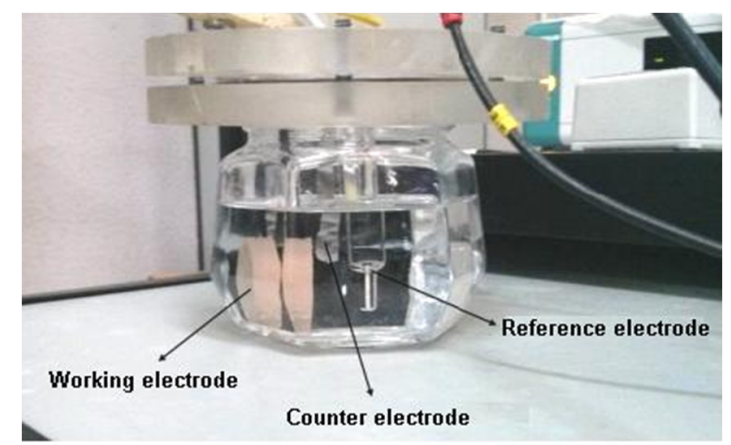

Fig. 4. Conventional polarization cell 
The polarization curves were recorded with an Autolab potentiostat, Type III, by varying the Voltage at $60 \mathrm{mV} / \mathrm{min}$ over a range of $-250 \mathrm{mV}$ to $+250 \mathrm{mV}$ with respect to open circuit Voltage. All measurements were carried out at a constant temperature of $25^{\circ} \mathrm{C}$ and without agitation. A solution of saline water containing $3.5 \%$ (\% mass) of $\mathrm{NaCl}, 800 \mathrm{mg} / \mathrm{L}$ of $\mathrm{MgCl}_{2}$ and $600 \mathrm{mg} / \mathrm{L}$ of $\mathrm{CaCl}_{2}$ with the $\mathrm{pH}$ set between 7.2 and 8.0 was used. Into the saline solutions were added, in each test, $100,500,1000$ and $5000 \mathrm{mg} / \mathrm{L}$ of sodium hypochlorite, $10 \%$ by mass.

\section{RESULTS AND DISCUSSION}

\section{A. Weight Loss Measurements}

The test results of the weight loss of copper-nickel alloy coupons in the saline solutions with 100, 500, 1000 and $5000 \mathrm{mg} / \mathrm{L}$ sodium hypochlorite, $10 \%$ (by mass) are presented in Figure 5.

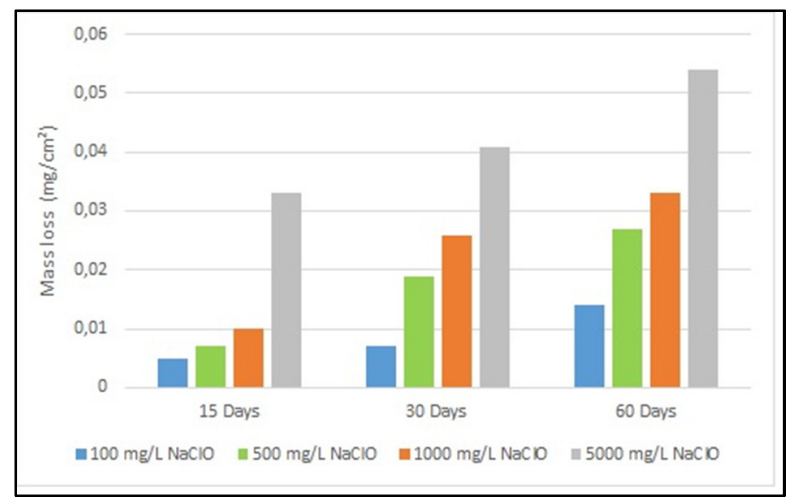

Fig. 5. Mass loss of copper-nickel alloy in saline solution with $\mathrm{NaClO}$, average of three coupons

Table I presents the results of the corrosion rate (mm/year) of copper-nickel alloy coupons in saline solution with additions of $\mathrm{NaClO}$ and exposure time of 60 days.

TABLE I. CORROSION RATE OF COPPER-NICKEL ALLOY COUPONS IN SALINE SOLUTION WITH ADDITIONS OF SODIUM HYPOCHLORITE

\begin{tabular}{|c|c|}
\hline $\mathbf{N a C l O}(\mathbf{m g} / \mathbf{L})$ & Corrosion rate $(\mathbf{m m} /$ year) \\
\hline 100 & 0.007 \\
\hline 500 & 0.010 \\
1000 & 0.014 \\
\hline 5000 & 0.045 \\
\hline
\end{tabular}

The mass loss assays (Figure 6 and Table I) showed that the increase in $\mathrm{NaClO}$ in the saline solution and the immersion time promoted the loss of mass copper-nickel alloy, meaning that the corrosion rate can be considered to be low to moderate, based on Table II as proposed by [6]. Figure 6 shows the copper-nickel alloy coupons after immersion tests in saline solution with $5000 \mathrm{mg} / \mathrm{L} \mathrm{NaClO}$ at 15,30 and 60 days. In these coupons, localized corrosion can be observed after the removal of corrosion products. Figures 7 and 8 show other aspects of the corrosion deposits, pitting and crevice corrosion, in coppernickel alloy coupons immersed in a saline solution with $5000 \mathrm{mg} / \mathrm{L}$ sodium hypochlorite.
TABLE II. AVERAGE CORROSION RATE [6]

\begin{tabular}{|c|c|c|}
\hline \multirow{2}{*}{ Corrosiveness } & \multicolumn{2}{|c|}{ Average corrosion rate } \\
\cline { 2 - 3 } & $\mathbf{m m} /$ year & $\mathbf{m m} /$ year \\
\hline $\begin{array}{c}\text { Low } \\
\text { Moderate }\end{array}$ & $<0.025$ & $<1.0$ \\
\hline High & $0.025-0.12$ & $1.0-4.9$ \\
\hline Severe & $>0.25$ & $5.0-10$ \\
\hline \multicolumn{2}{|c}{} \\
\hline
\end{tabular}

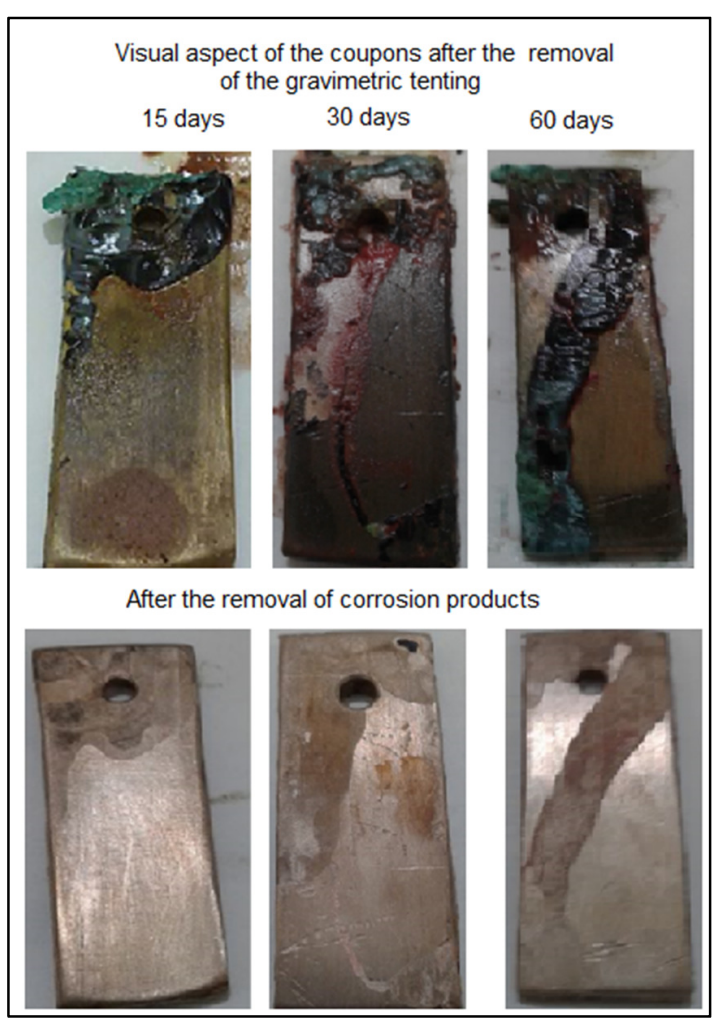

Fig. 6. Copper-nickel alloy coupons in gravimetric testing in saline solution with $5000 \mathrm{mg} / \mathrm{L}$ sodium hypochlorite

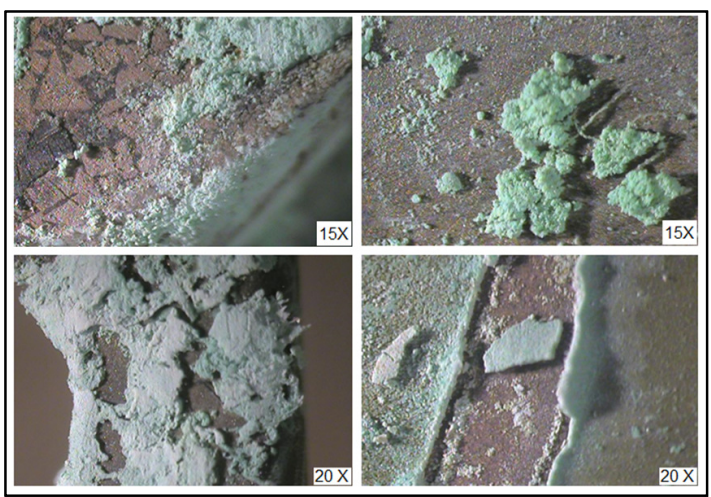

Fig. 7. Corrosion product of copper-nickel alloy coupons with $5000 \mathrm{mg} / \mathrm{L}$ of sodium hypochlorite

X-ray diffraction analysis of the corrosion deposits on the surfaces of the coupons showed the predominance of copper chloride hydroxide $\left(\mathrm{Cu}_{2}(\mathrm{OH})_{3} \mathrm{Cl}\right)$ and small amounts of copper chloride $\left(\mathrm{CuCl}_{2}\right)$ and nickel chloride $\left(\mathrm{NiCl}_{2}\right)$. According to [7], for copper in pure water during the primary corrosion reaction, 
a cuprous oxide film $\left(\mathrm{Cu}_{2} \mathrm{O}\right)$ is produced that is predominately responsible for corrosion protection.

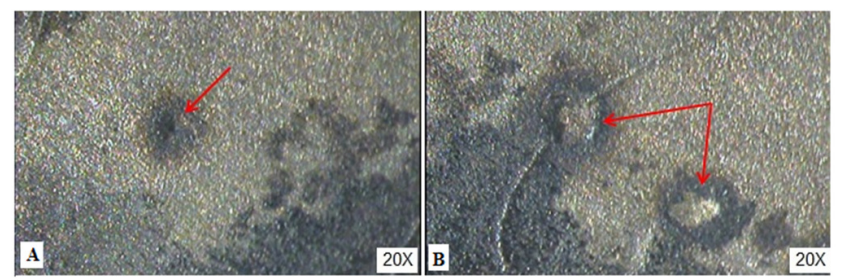

Fig. 8. Pitting (A) and crevice (B) corrosion in copper-nickel alloy coupons with $5000 \mathrm{mg} / \mathrm{L}$ of $\mathrm{NaClO}$

Authors in [8, 9] report that in salt solutions, with oxygenation and the addition of oxidizing substances, cuprous oxide can initially react to form multilayer structures, for example, basic copper chloride to $\mathrm{CuCl}_{2}, \mathrm{Cu}(\mathrm{OH})_{2}$ or $\mathrm{Cu}_{2}(\mathrm{OH})_{3} \mathrm{Cl}$. These products do not adhere well to the surface and can be easily removed. According to [10], depending on the concentration of free chlorine in the form of $\mathrm{NaClO}$, the corrosion rates of copper-nickel alloys saline solution are in the range of 0.07 to $1.27 \mathrm{~mm} /$ year.

\section{B. Electrochemical Tests}

In Figure 9, polarization curves were only placed for assays with and without $5000 \mathrm{mg} / \mathrm{L} \mathrm{NaClO}$. The curves for solutions with concentrations of 100,500 and $1000 \mathrm{mg} / \mathrm{L}$ were superimposed and were not significantly different from the curve for the solution without $\mathrm{NaClO}$. The anodic and cathodic reactions are affected by the addition of $\mathrm{NaClO}$. The intersection of the anodic and cathodic curves showed an increase in the intensity of current $\left(\log \mathrm{I}, \mathrm{A} / \mathrm{cm}^{2}\right)$.

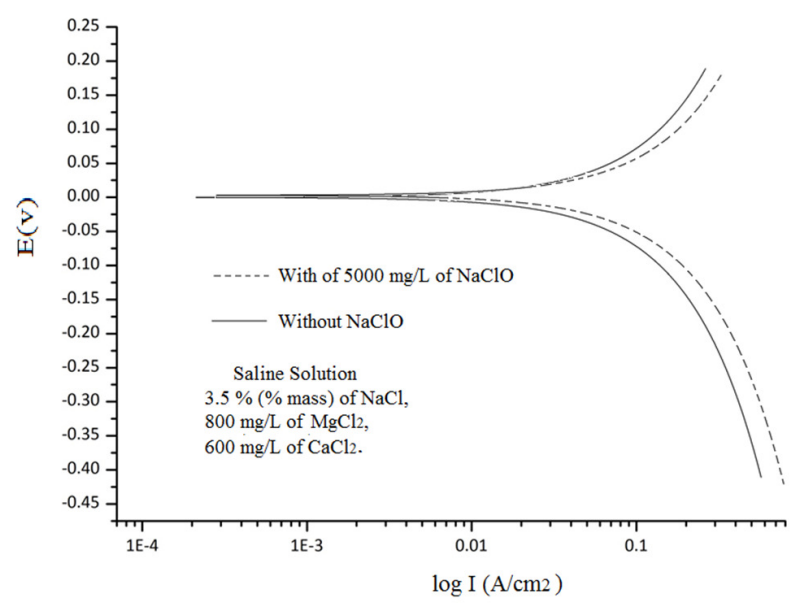

Fig. 9. Current density-potential curves of copper-nickel alloy with and without addition of sodium hypochlorite

\section{CONCLUSION}

Based on laboratory tests and inspection of seawater pumps, it is concluded that:

- The corrosion in copper-nickel alloy coupons was caused by high concentration of $\mathrm{NaClO}(5000 \mathrm{mg} / \mathrm{L})$, while the concentration of 0.2 to $0.5 \mathrm{mg} / \mathrm{L}$ of $\mathrm{NaClO}$ indicated from the uptake of seawater did not cause any corrosion problems and prevented the proliferation of microorganisms in seawater.

- Corrosion in the interior of the pumps was due to continuous $\mathrm{NaClO}$ injection, even when the pump was completely stopped.

- Modification of the project with installation of pilot valves monitoring the injection of $\mathrm{NaClO}$ could prevent corrosion of copper-nickel pumps.

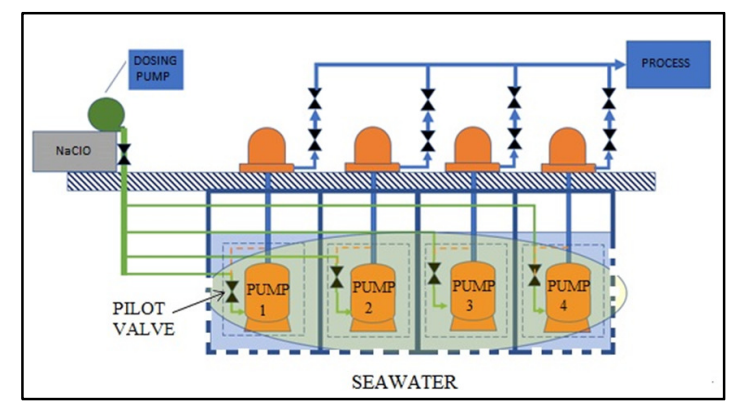

Fig. 10. Modification proposal for of seawater pumps

\section{REFERENCES}

[1] C. Kapsalis, G. Schmitt, R. Feser, B. Sagebiel, S. Wilmes, M. Macziek, "New investigations on critical wall shear stresses of CuNi alloys in natural and artificial seawater", Eurocorr - 2011, Stockholm, Sweden, September 4-8, 2011

[2] W. Schleich, "Typical failures of $\mathrm{CuNi}$ 90/10 seawater tubing systems and how to avoid them", Eurocorr - 2004, Nice, France, September 1216,2004

[3] J. H. Michel, I. Richardson, C. Powell, B. Phull, "Development of copper alloys for seawater service from traditional application to stateof-the art engineering", Corrosion 2017, New Orleans, USA, March 2630,2017

[4] A. L. Ma, S. L. Jiang, Y. G. Zheng, W. Ke, "Corrosion product film formed on the $90 / 10$ copper-nickel tube in natural seawater: composition/structure and formation mechanism", Corrosion Science, Vol. 91, pp. 245-261, 2015

[5] ASTM, ASTM G31-72, Standard Practice for Laboratory Immersion Corrosion Testing of Metals, ASTM International, 1999

[6] NACE, NACE-RP0775-2005, Standard Recommended Practice: Preparation, Installation, Analysis, and Interpretation of Corrosion Coupons in Oilfield Operations, NACE, 2005

[7] M. Pourbaix, "Licoes de Corrosao Eletroquimica", in: Brasileira de Corrosao-ABRACO1, pp. 338-342, 1988 (in Portuguese)

[8] F. J. Kievits, F. P. Ijsseling, "Research into the corrosion behavior of CuNi10Fe alloys in seawater", Materials and Corrosion, Vol. 23, No. 12, pp. 1084-1096, 1972

[9] A. H. Tuthill, "Guidelines for the use of copper alloys in seawater", Materials Performance, Vol. 26, No. 9, pp. 12-22, 1987

[10] H. H. Uhlig, Uhlig's Corrosion Handbook, John Wiley \& Sons, 2011 